Ethiopian Journal of Environmental Studies \& Management 10(4): 472 - 481, 2017.

ISSN:1998-0507

doi: https://dx.doi.org/10.4314/ejesm.v10i4.5

Submitted: December 05, 2016

Accepted: May 25, 2017

\title{
“POLLUTER PAYS OR POLLUTER ENRICHING THE RETAILERS": THE CASE OF PLASTIC BAG LEVY FAILURE IN BOTSWANA
}

\author{
*MADIGELE, P.K. ${ }^{1}$ AND MOGOMOTSI, G.E.J. ${ }^{2}$ \\ ${ }^{1}$ Okavango Research Institute, University of Botswana, Maun, Botswana \\ ${ }^{2}$ Department of Legal, University of Botswana, Gaborone, Botswana
}

\begin{abstract}
It has been almost ten years since the introduction of plastic levy in Botswana. The levy was introduced as part of measures to combat littering of plastic bags and reduce their negative effects on the environment. The main objective of environmental taxes is to pass on the cost of pollution on polluters. This paper uses exploratory research method of reviewing and/or assessing available literature with respect to the implementation of environmental tax in Botswana. This paper investigates the effectiveness of the plastic levy in ensuring that the public or the government does not shoulder the burden of waste management since its introduction in Botswana. The plastic levy is not being used for the purposes it was intended for due to the failure of the government to collect the levied monies from business owners. The study concludes that there are institutional vacuums and failures that hinder the effective implementation of the plastic levy in Botswana. In the interim, this paper calls for the immediate suspension of the failed levy which is enriching the few businesses owners in the name of the environment.
\end{abstract}

Key Words: Plastic bags, Environmental tax, Polluter Pays Principle, Environmental management

\section{Introduction}

Plastic has become of the most useful material in the last century, while attaining the status of one of the best things if not a miracle product to appear to humankind. It is on the other hand viewed by some as a mass produced curse filling up landfill, choking wildlife and littering the forests (Larsen and Venkova, 2014). Plastics have proved themselves valuable social assets to households throughout the third world. However, due to the fact that they are readily and cheaply available, the incentive to re-use them drops sharply (Leiman, 2011).

Plastic bags in Botswana are of use to consumers but at a cost to the environment (Dikgang and Visser, 2012). The widespread use of easy to access, very cheap and low quality plastic bags has resulted in a negative visual externality with no one taking the responsibility for the used bags littering both urban and rural streets(Leiman, 2011). Environmental degradation caused by littering of plastic bags has been and still is a problem in Botswana. This has 
seriously affecting some sectors which are the main contributors to the national economic being agriculture and tourism (Dikgang and Visser, 2012).

There is consensus among policy makers that packaging presents a major environmental problem (Nhamo, 2007). The regulation of the use of plastic bags in African is two-folds. Rwanda which is currently rated as the cleanest country in the continent had adopted a total ban on the use of plastic bags (Chitombe, 2014). The other type of plastic regulation followed by Botswana and South Africa is the partial ban through the setting of minimum thickness of plastic bags which co-exists with a levy on plastic bags (Chitombe, 2014).

The Government of Botswana introduced an upstream tax to be levied on the sale of plastic bags in 2007 on producers of bags with the intent of the revenue to go towards environmental issues (Gerrity, 2015). This levy is collected at the point of sale in retail outlets, a departure from the previous practice in which the retailers provided plastic bags free of charge to the consumers. The levy is intended to discourage the use of plastic bags, increase recycling of the plastic bags and to fund refuse collection services by government (Leiman, 2011).

This paper discusses the place of plastic bag levy within the broader debate of Polluter Pays Principle. It assesses the application of the Principle in Botswana in seeking to make the determination whether the collection of the levy has made contributions to relieve the government from bearing the costs of pollution made by the use of plastic bags. The paper, however, does not seek to make an investigation and/or assessment as to whether the levy has managed to reduce the use of plastic bags in Botswana.

\section{Materials and Methods}

This article was formulated using a qualitative method of research. Different types of literature which included books, journal articles, newspapers, governmental policies among others were reviewed. The identification, evaluations and interpretation of available research relevant to a particular research question, or topic of interest was done systematically (Kitchenham, 2004; Kitchenham et al., 2009).

The electronic databases such as Google Scholar, EBSCO Discovery Service and Environment Index were searched systematically using keywords such as plastic bags; environmental tax; polluter pays principle; environmental management among others. The selected papers were then screened and relevant papers were selected using automatic snowballing method.

The Environment as a Common Pool Resource: Using Taxation to Avert the Tragedy of Commons

Common pool resource (CPR) theory is a response to arguments that collective action for mutually beneficial goals, including resource management, is unfeasible in large groups without coercion or private property rights (Fleischman et al., 2014). Difficulty in excluding users, combined with a CPR's subtractability, create management vulnerabilities that can result in resource degradation, often referred to as the "tragedy of the commons" (Heikkila and Carter, 2014). The difficulty of exclusion means that if some individuals invest in protecting a $\mathrm{CPR}$, others might still benefit without 
contributing to its management. If users to the various resources do not restrain their use of a CPR or contribute to CPR management, the result is often the depletion or degradation of the CPR's quality (Heikkila and Carter, 2014). The environment benefits the entire society with near impossibility of exclusion. It hence qualifies as a CPR susceptible to degradation. There are various mechanisation in place to be used to protect the environment. For purposes of this paper only taxation will be discussed.

The management problems of CPRs are self-evident, whether they be of resource depletion or environmental degradation, lack of appropriate institutions for management, or conflicting claims over resources (Adams et al., 2003). The sustainable use and management of CPRs requires a deep understanding about the causes of conflict in resource use. It is noted that conflicts over the management of CPRs are not simply material, as they also depend on the perceptions of the protagonists (Adams et al., 2003). Governments may achieve sustainable management of CPRs through punitive taxes against those who misuse or contaminate the resources or through positive taxation by pooling together taxes to subsidise behaviour that encourages the preservation of the environment.

Tragedy of the commons refers to the depletion of shared resources by individuals acting independently and rationally, according to one's selfinterest, despite knowing that an abuse of the common resource is contrary to those individuals' long-term best interests (Hardin, 1968). Due to the multiplicity of player and stakeholders, it is often difficult to reach a workable and effective solution with the presence of free-rider problem (Asafu-Adjaye, 2000).

The externalities are often curbed through corrective tax imposition to align marginal private costs to social costs (Santos et al., 2009). The theoretical assessment of the use of tax to promote environmental and/or natural resource management is discussed below by the exposition to two intertwined concepts of environmental tax shift and the Polluter Pays Principle.

\section{Theoretical Background of Corrective Taxation in Environmental Management \\ Environmental Tax Shift: Exploring the Concept}

This paper defines environmental tax shift as the process of shifting the burden of tax '... from economic 'goods' to environmental 'bads', from what is socially desirable, such as employment, income and investment, to what is socially undesirable, such as pollution, resource depletion and waste" (Bosquet, 2000). Pollution is a negative environmental externality that can be caused directly by both producing and consuming goods such as motor vehicles which emit air pollutants. The cost incurred by the society due to the environmental externalities should be reflected by the environmental tax rate set.

The introduction of environmental taxes leads to a significant reduction on other forms of taxes such as income tax, and to the development of technologies designed for the betterment of the environment and the society at large, and then the shift is more likely to be embraced by the public (Taylor et al., 1999). Furthermore, environmental tax 
shift provides an incentive for protecting the environment and safeguarding natural resources for future generations while providing a disincentive for depletion of natural resource and general damage to the environment. The environmental tax shift account for externalities, it contributes to economic efficiency by aligning the prices of goods and services to social costs and can encourage the market to adjust in a way that promotes conservation and environmental protection (Santos et al., 2009).

Despite these positives, the environmental tax shift principle has disadvantages. Environmental taxes have regressive distributional repercussions leading to the poor making a disproportionate contribution towards such taxes relative to those who are welloff (Metcalf, 1998). These comparisons are made relative to the incomes earned by people in different financial classifications. The imposition of environmental taxes entails administration costs, in most countries, it the application of environmental tax shift in a cost-effective way of meeting the set environmental obligations and targets is difficult (Taylor et al., 1999; Anderson, 2007).

Amidst the debates on the merits and demerits of imposing environmental taxes, there is a consensus among academics and policy-makers that the environment needs to be protected. The environment is a public good and a common-pool resource with two key features of non-rivalry and nonexcludability, it is prone to misuse, pollution and mismanagement. Environmental tax shift gives the producer and/or supplier of goods and services that are environmentally unfriendly a disincentive to supply more of the good or service (Metcalf, 1998). Similarly, environmental taxes provide an incentive for users of goods and services with the potential of harming the environment to use less of such goods and services.

Most governments around the world have, for many decades, crafted and implemented price-based fiscal instruments including taxes and subsidies in order to meet their social, environmental and macroeconomic goals (Gillingham and Sweeney, 2010). The adoption and implementation of a pricebased fiscal instrument, either taxes or subsidies, is dependent on factors such as severity of the problem at hand, its type, and the cost of implementing the instrument among other factors (Timilsina and Dulal, 2008).

The principle of taxes have been extended to either discourage the use goods and services that degrade natural and environmental resources or to encourage the sustainable use of goods and services that protect and conserve such resources. Environmental taxes are intended to ensure that the scarce public finance is not used towards pollution and waste management. It is the polluters who should take care of by-products of their activities. The idea is that as long as people access free but expensive waste management facilities, the necessary attitude shift among users towards greater consideration for the environment will be difficult to achieve (Yuen, 2005).This paradigm shift is in literature referred to as the "Polluter Pays Principle" a concept properly so called. A brief discussion on the origins and application of the Polluter Pays Principle in environmental management follows immediately below. 
Overview of the Polluter Pays Principle

The idea of Polluter Pays Principle is historically traceable to The Dialogues of Plato: The Laws wherein Plato stated that, "If anyone intentionally spoils the water of water of another...let him not only pay the damages, but purify the streams or cisterns which contains the water" (Khan, 2015). This is achieved through the introduction of one form of tax or the other to ensure that the polluter bears the cost of pollution.

Taxation has a social, economic and political role in society. It is increasingly being used as an environmental tool through the of use environmentally related taxes to provide an incentive to polluters to modify their production and consumption behaviour (Joseph, 2014). There are four general versions of the Polluter Pays Principle; (i) economically, it promotes efficiency; (ii) legally, it promotes justice; (iii) it promotes harmonisation of international environmental policies; and (iv) it defines how to allocate costs within a State (Bugge, 1996).

The Polluter Pay Principle is one of the fundamental principles of modern environmental policies. It simply means that the cost of pollution abatement should be paid by the polluters and not by their governments (Munir, 2013). The doctrine or concept of Polluter Pays Principle has both the legal and economic dimensions.

The Polluter Pays Principle has been considered since 1990 as a general principle of international environmental law (Nordic Council of Ministers, 1996). The worldwide recognition of the Polluter Pays Principle was the culmination of a trend earlier in evidence with its embodiment in the Single
European Act in 1987 and in the Treaty of Maastricht in 1992 (Luppiet al., 2012).

Implementation of the Polluter Pays Principle

As a general rule, sound economic analysis of pollution and environmental problems must also be based on the principle of responsibility to forcing polluters to bear the costs of their activities is good economics too (Cordato, 2001). This does not only advance fairness and justice, but also enhances economic efficiency (Cordato, 2001). Ideally, the polluters should, without the exercise of any governmental coercive force, be taking care of the result of their pollution. However, due to the failure of market self-regulation, it has become a necessity to introduce regulatory and/or legislative instruments to ensure that market players take responsibility of their actions.

The implementation of the Polluter Pays Principle by sovereign states has been done enjoyed different incarnations in national legal systems, some governments implement the principle through direct regulation that creates economic incentives, leading the polluter to bear the cost of the environmental harm caused by its activity (Luppe et al, 2012).

The concept of market failure is the starting point for most economic theorists in discussing environmental damage. It is suggested that the cost of environmental degradation has not been priced in the market place, and therefore the market fails to recognise its significance (Lockhart, 1997). In theory, taxes and charges put a price on this externality, or negative social cost, associated with environmental damage (Lockhart, 1997). It is argued environmental taxes designed 
in line with the Polluter Pays Principle are promising instruments to combat or least curtail environmentally negative behaviour (Stavins and Whitehead, 1992). Such taxes are cost-effective relative to most other alternative policy measures because taxes can be designed to reach established goals at low social costs (Sterner, 1999)

In most case, the Polluter Pays Principle takes the form of a tax collected by governments and levied per unit of pollution emitted into the air, land and/or water (Meywen and Sebastien, 2013). As a policy instrument for the control of pollution, a tax on emissions, spills and/or contamination will reduce pollution because possible polluters will reduce emissions and spills in order to avoid paying the tax (Fullerton et al., 2001). Economists argue that pollution tax will generally be more cost-effective at reducing pollution than regulations (Beder, 1996).

The Polluter Pays Principle is epitomised in international law in the 'Trail Smelter' case. The arbitration tribunal held that the polluting state (Canada) should pay compensation to the United States for the trans-boundary harm caused by activities in its territory (Joseph, 2014). The owner and operator of the polluting smelter was not a party to the arbitration, in this instance the strict liability was invoked (Joseph, 2014). The practical effect of the application of the Principle results in the correction of inefficient market outcomes to set equal the social cost of the negative environmental externalities (Nye, 2008).

From Polluter Pays to enrichment of business owners: The failure of plastic levy in Botswana?
Botswana's waste management strategy incorporates the Principle of Prevention. Its objective is to minimise environmental pollution through the introduction of appropriate management practices such as the Polluter Pays Principle (Republic of Botswana, 1998).

In 2007, the government introduced a ban of plastic bags with less than minimum thickness, and bag tax to run concurrently. This is aimed at reducing unnecessary usage of excessive amounts plastic bags for packaging in an effort to reduce their negative externalities to the environment. Prior to the imposition of the regulation, retailers in Botswana incorporated the costs of plastic bags into the prices of products sold while ostensibly offering the bags for 'free' to their customers. Since the inception of the plastic levy in Botswana, the government of Botswana has failed to collect the plastic levy from the retailers who continue to demand payment for packaging goods for consumers as per the regulations (Lemmenyane, 2015). As a result of lack of mechanisms and/or willingness to collect the levy as it was supposed to be collected by government, it is now benefiting the retailers as part of their profit (Letswamotse, 2015).

There has been controversy and/or confusion within the government as to whether there is a plastic levy in Botswana, with the Ministry of Trade and Industry denying that there is plastic levy to be collected by the retailers of behalf of the government (Botswana Press Agency, 2015). While the Ministry of Environment, Wildlife and Tourism professed knowledge of the existence of the plastic levy notwithstanding that the ministry responsible for the imposition of 
the said levy is the Ministry of Trade and Industry (Keaketswe, 2015).

The inability to collect the plastic levy is attributed to the institutional failures or deficiencies that hinder the efficient and effective implementation of the tax. It is noted that when the plastic levy was introduced, collection logistics were not properly worked out (Baaitse, 2015). Almost a decade later, nothing has been done to ensure that the polluter, i.e. the consumers who pay the levy at retailers' point of sale, indeed pays for their pollution. Essentially, waste management, especially of plastic bags litter, remains the responsibility and the financial burden of the government notwithstanding that the private sector is collecting millions of Pula purportedly on behalf of the government.

In terms of the Polluter Pays Principle, both producers and consumers should pay the full social costs of their actions. However, the evident lack of institutional preparedness by the government to direct collection of plastic levies has enabled retailers to benefit at the expense of both the consumers and the environment. While consumers believe to be paying the full social costs of using plastic bags, they are in fact contributing to the sales and profits of the retailers. The retailers, therefore, have no incentive of discontinuing the sale of plastic bags, or at least introducing environmentally friendly alternatives to consumers.

Recently, the Ministry of Wildlife, Environment and Tourism commented that the government on advice from the tax authority has decided not to pursue the plastic levy any further due to the complexities in the collection and/or administration of such levy (Pinielo,
2016). This is quite interesting in that the government of Botswana is successfully administering and collecting a similar levy being administered to retailers in the form of alcohol levy without any difficulties which P298, 731 million was collected in 2014/2015 (Mooka, 2016).

One of the crucial roles of the government is to correct market failure through the implementation of policies and other mechanism. The intervention of the government to correct market failure triggered by environmental externalities associated with the excessive use of plastic bags through introducing the plastic levy is hence justifiable. However, the lack of regulatory framework to enable the effective collection of levies from the consumers to the government has proven costly to the very same environment the levy was designed to protect.

\section{Conclusion}

This paper discussed the role of environmental tax as a mechanism in reducing or curbing environmental degradation. It further discussed the nature of plastic levy in operation Botswana which is a partial ban of use of plastic bags, a route taken by other countries such as South Africa and Ireland. It has been almost a decade after the introduction of a plastic levy in Botswana, in line with the Polluter Pays Principle which is entrenched in the national Waste Management Plan.

Contrary to the policy objective of ensuring that the funds collected by the retailers from consumers goes towards the National Environment Fund to finance conservation and waste management efforts, the money remains unclaimed by the government from 
retailers. Essentially, since the introduction of the plastic levy in 2007 to date, the retailers have reported or treated the unclaimed levy as part of their profits. As a result, the government is continuing to bear the costs of pollution caused by plastic bags litter notwithstanding that the polluters are made to contribute towards the same. There is a clear policy failure in the implementation of the polluter pays principle in Botswana which calls for immediate review of the same. The government is called upon to prioritise environmental management which has a bearing on the second highest earner of government revenue in Botswana after diamond exports. It is improper for the public to be taxed for use of plastic bags when such taxes do not end in public coffers to be used toward their intended purposes. In the interim, the failed levy should be suspended. This is because it is enriching the few businesses owners in the name of the environment. Making the public pay for waste management through the plastic bag levy which ends in the pockets of retailers is unfair to tax payers.

The failure to collect the levy by the government is indicative of the institutional failure and enforcement deficiencies in Botswana's environmental management landscape. It is submitted that the glaring differences in the collection and administration between the alcoholic beverages levy and plastic bags levy in an indictment of the government of Botswana on its willingness to fully implement environmental management policies and laws.

\section{References}

Adams, W.M., Brockington, D., Dyson, J. and Vira, B. (2003). Managing
Tragedies: Understanding Conflict over Common Pool Resources. Science, 302(1958): 1915-1916.

Baaitse, F. (2015). Gov't failing to collect plastic levy. Weekend Post.

Beder, S. (1996). Charging the Earth: The Promotion of the Price-Based Measures for Pollution Control. Ecological Economics, 16: 51-63.

Bosquet, B. (2000). Environmental Tax Reform: Does it work? A Survey of the Empirical Evidence. Ecological Economics, 34: 19-32.

Botswana Press Agency. (2015). Botswana: No Legal Instrument On Plastic Bags Levy. Daily News.

Bugge, H. (1996). The Principles of "Polluter Pays" in Economics and Law. In E. Eide, \& R. van den Bergh, Law and Economics of the Environment (pp. 53-90). Oslo: Jurdisk Forlag.

Chitombe, J.W. (2014). The plastic bag 'ban' controversy in Zimbabwe: An Analysis of policy isses and local responses. International Journal of Development and Sustainability, 3(5): 1000-1012.

Cordato, R. (2001). The Polluter Pays Principle: A Proper Guide for Environmental Policy. Washington D.C: Institute for Research on the Economics of Taxation.

Dikgang, J. and Visser, M. (2012). Behavioural Response to Plastic Bag Legislation in Botswana. South African Journal of Economics, 80(1): 123-133.

Fink, S. (2000). Environmental Law in a Developing Country: Botswana. Pretoria: University of South Africa.

Fleischman, F., Loken, B. and GarciaLopez, G.V.-T. (2014). Evaluating 
the utility of common-pool resource theory for understanding forest governance and outcomes in Indonesia between 1965 and 2012. International Journal of Commons, 8(2): 304-336.

Fullerton, D., Hong, I. and Metcalf, G. (2001). A Tax on Output of the Polluting Industry Is Not a Tax on Pollution: The Importance of Hitting the Target. In C. Carraro, \&G. Metcalf, Behavioral and Distributional Effects of Environmental Policy (pp. 13-44). Chicago: University of Chicago Press.

Gerrity, B. (2015). Consumer Choice and Environmental Taxation . Tacoma: University of Puget Sound.

Gillingham, K. and Sweeney, J. (2010). Market failure and the structure of externalities. In A. Jorge Padilla, \& R. Schmalensee, Harnessing Renewable Energy (pp. 69-92). RFF Press.

Grossman, M.R. (2007). Agriculture and the Polluter Pays Principle. Electronic Journal of Comparative Law, 11(3): 1-66.

Hardin, G. (1968). The Tragedy of the Commons. Science, 162(3859), 1243-1248.

Heikkila, T. and Carter, D. (2014). "Common Pool Resources.". In E. Wohl, Oxford Bibliographies. New York: Oxford University Press.

Joseph, S. (2014). The Polluter Pays Principle and Land Remediation: A Comparison of the United Kingdom and Australian Approaches. Australian Journal of Environmental Law, 1(1), 24-36.

Khan, M. (2015). Polluter-PaysPrinciple: The Cardinal Instrument for Addressing Climate Change. Law, 4: 638-653.

Kitchenham, B. (2004). Procedures for performing systematic reviews (pp. 1-33). Keele: Keele University. Available

at: http://www.inf.ufsc.br/ aldo.vw/kit chenham.pdf[Accessed: 14/1/2016]

Kitchenham, B., Pearl Brereton, O., Budgen, D., Turner, M., Bailey, J. and Linkman, S. (2009). Systemati literature reviews in software engineering - a systematic literature review. Information and Software Technology, Empirical Software Engineering 51(1): 7-15.

Larsen, J. and Venkova, S. (2014). The Downfall of Plastic Bag. Retrieved from Population Press: https://populationpress.org/2014/05/ 05/the-downfall-of-the-plastic-bagby-janet-larsen-and-savinavenkova/

Leiman, A. (2011). Taxation and Regulation of Plastic Shopping Bags in Botswana and South Africa. Retrieved from Resources for the Future: http://www.rff.org/blog/2011/taxati on-and-regulation-plastic-shoppingbags-botswana-and-south-africa

Lemmenyane, T. (2015). The Proposal to Ban Plastic Bags was Ill-Advised. Sunday Standard.

Lockhart, J. (1997). Environmental Tax Policy in the United States: Alternatives to the Polluter Pays Principle. Asia-Pacific Journal of Accounting, 4(2): 219-239.

Luppi, B., Francesco, P. and Rajagopalan, S. (2012). The rise and fall of the polluter-pays principle in developing countries. 
International Review of Law and Economic, 32: 135-144.

Metcalf, G.E. (1998). A Distributional Analysis of an Environmental Tax Shift. Cambridge, Massachussets: National Bureau of Economic Research.

Meywen, H. and Sebastien, L. (2013). Environmental Justice and Ecological Debt in Belgium: The UMICORE Case. In J. Healy, L. Martinez-Alier, M. Temper, M. Walter, \& J. Gerber, Ecological Economics from the Ground Up (pp. 403-429). Oxon: Routledge.

Mooka, Y. (2016). Beer guzzlers contribute P300m to Alcohol Levy. Botswana Guardian.

Munir, M. (2013). History and Evolution of the Polluter Pays Principle: How an Economic Idea Became a Legal Principle? Retrieved from Social Science Research Network: http://dx.doi.org/10.2139/ssrn.2322 485

Nhamo, G. (2007). Environmental Law and policy reform surrounding packaging waste management in South Africa. South African Journal of Environmental Law and Policy, 14: 136-157.

Nordic Council of Ministers. (1996). The Use of Economic Instruments in Nordic Environmental Policy. Copenhagen: TemaNord.

Nye, J. (2008). 2008 Regulations, 31(2): 32-37.
Republic of Botswana. (1998). Botswana's Strategy for Waste Management . Gaborone: Government Printer.

Santos, G., Behrendt, H., Maconi, L., Shirvani, T. and Teytelboym, A. (2009). Externalities and economic policies in road transport. Research in Transportation Economics, 28(1): 2-45.

Stavins, R. and Whitehead, B. (1992). The Greening of America's Taxes: Pollution Charges and Environmental Protection. CSIA Discussion Paper 92-03. Cambridge, MA: Kennedy School of Government, Harvard University.

Sterner, T. (2007). Fuel taxes: An Important Instrument for Climate Policy. Energy Policy, 35(6): 31943202.

Taylor, A., Jaccard, M. and Olewiler, N. (1999). Environmental Tax Shift: A Discussion Paper for British Columbians. Victoria: Government of British Columbia.

Timilsina, G. and Dulal, H. (2008). Fiscal Policy Instruments for Reducing Congestion and Atmospheric Emissions in the Transport Sector: A Review. Washington D.C: The World Bank Group.

Yuen, W. (2005). A study of polluter pays principle policy in Hong Kong. Hong Kong: University of Hong Kong. 